\title{
Taxonomy and Distribution of Equitius in Eastern Australia (Opiliones: Laniatores: Triaenonychidae).
}

\author{
GLENN S. HunT \\ Education Section, Australian Museum, P.O. Box A285, \\ Sydney South, N.S.W., 2000
}

\begin{abstract}
The genus Equitius is revised. Jenolanicus Roewer, 1915, Monacanthobunus Roewer, 1915, Monoxyomma Pocock, 1903 and Rydrusa Roewer, 1931 = new synonyms of Equitius Simon, 1880. Three new combinations are established: E. altus (Forster, 1955) (Jenolanicus), E. spinatus (Pocock, 1903) (Monoxyomma) and E. tambourineus (Roewer, 1921) (Jenolanicus). Four new synonymies are proposed: Jenolanicus armatus Roewer, 1915 and Monacanthobunus continentalis Roewer, $1915=E$. doriae Simon, 1880; E. affinis Roewer, 1923 and Rydrusa armata Roewer, $1931=E$. tambourineus (Roewer, 1921). Three new species are described: E. formidabilis, $E$. montanus and E. richardsae. A key to all seven species is given.

Discontinuous mountain blocks and major river valleys are seen as factors influencing the present distribution of species in south-eastern Australia. An isolated cave population of $E$. altus is noted.
\end{abstract}

HunT, GLENN S., 1985. Taxonomy and distribution of Equitius in eastern Australia (Opiliones: Laniatores: Triaenonychidae). Records of the Australian Museum 36: 107-125.

Keywords: Taxonomy, Equitius, Opiliones, eastern Australia, speciation, cavernicolous

Equitius is the dominant harvestman genus inhabiting moist forest and woodland in the coastal ranges and plains of south-eastern Australia, from southern Queensland (latitude $27^{\circ} \mathrm{S}$ ) to the Shoalhaven River, N.S.W. (latitude $35^{\circ} \mathrm{S}$ ). Its species are perhaps the commonest large arachnids to be found under logs on the forest floor, but the importance of the genus has not previously been recognised because of failure by authors to recognise the taxonomic unity of these species.

\section{Materials and Methods}

Type material of all nominal species has been examined and reassessed. The following abbreviations have been used to indicate the present location of material examined:

\footnotetext{
AM The Australian Museum, Sydney

ANIC Australian National Insect Collection, Canberra

BM British Museum (Natural History), London

MCSN Museo Civico di Storia Naturale, Genoa

PM Muséum National d'Histoire Naturelle, Paris

MV Museum of Victoria, Melbourne

NHRMS Naturhistoriska Riksmuseet, Stockholm

NMS NaturMuseum Senckenberg, Frankfurt am Main

UQ University of Queensland, Entemology Dept., Brisbane
}

Terminology closely follows that of Forster (1954). Tergal areas 1-5 are abbreviated to TAl, TA2, etc. Methods of measuring specimens follow Hunt (1979).

Male dimorphism has been noted in all species of Equitius except E. formidabilis where only small samples are available. The phenomenon is described in detail elsewhere (Hunt, 1979). Form A males, which exhibit normal development of secondary sexual characteritics, are used for the description of males. Form B males show incomplete development of secondary sexual characteristics in body size, robustness of pedipalps and in the size and nature of certain spines on the pedipalps. Form B are not described here as inclusion would make each species description unduly long and complex. The specific status of these males can be determined from male genitalic characters which are the same as in Form A males, or by their presence in a large series of specimens in which the identity of Form A males and females has been determined.

Family Triaenonychidae Soerensen, 1886

Subfamily Triaenonychinae Pocock, 1903

Tribe Triaenonychini Pocock, 1903

Genus Equitius Simon, 1880

Equitius Simon, 1880: 100. - Roewer, 1915: 110, 1923: 606. Type-species: Equitius doriae Simon. 